\title{
SZENNAY ÁRON
}

\section{A vállalati társadalmi felelősségvállalás megközelítései és a fenntartható fejlödés}

\begin{abstract}
A tanulmány a vállalati társadalmi felelősségvállalás különböző irányzatainak a fenntartható fejlődéshez való viszonyát elemzi, különös tekintettel a megosztott értékteremtésre és a hármas optimalizációra. Az eredmények alapján az üzleti szereplők felelősségvállalása a jelenlegi gazdasági struktúra fenntartása, a fenntarthatóság gyenge definíciója érvényesítésének irányába mutat. A megosztott értékteremtés és a hármas optimalizáció egyaránt a vállalati felelősségvállalás üzleti szempontjait, a gazdasági érdek és a fenntarthatósági célok közötti kölcsönösen előnyös kapcsolatokat helyezi elötérbe. Bár a megosztott értékteremtés vizsgált irányzatai rendre a piacgazdaság újradefiniálását hirdetik, elemzésünk alapján kevés újdonságot mutatnak, csupán a társadalmi bizalom visszaszerzését, megtartását, valamint a különböző tanácsadók, illetve vállalatok márkaépítését szolgálják. A vizsgálat következtetései a hazai és nemzetközi szakirodalom feldolgozásán alapulnak.* Journal of Economic Literature (JEL) kód: M14, M21, Q56.
\end{abstract}

A fenntarthatóság, a fenntartható fejlődés kérdésköre napjaink egyik, ha nem a legaktuálisabb globális kihívása. A gazdasági növekedés hosszú távú fenntarthatatlanságát már a Római Klub 1972-es jelentése (Meadows és szerzőtársai [1972]) is prognosztizálta (lásd Kerekes és szerzőtársai [2018]). A környezeti problémák súlyosságát mutatja például, hogy a Világgazdasági Fórum 2020. évi Globális kockázati jelentése (WEF [2020]) szerint az öt legvalószínübb globális kockázat mindegyike (1. extrém időjárási viszonyok, 2. a klímaváltozás elleni harc kudarca, 3. természeti katasztrófák, 4. a biodiverzitás csökkenése, 5. emberi eredetü környezeti katasztrófák), a legnagyobb hatású kockázatok közül pedig három (1., 3. és 4.) környezeti jellegü. Az IPCC

* A tanulmány az MTA-BGE Makrogazdasági fenntarthatósági kutatócsoport mint munkahely keretében, a Támogatott Kutatócsoportok Irodájának támogatásával készült. A szerző a kutatócsoport tagja.

A szerző köszönetét fejezi ki Losoncz Miklósnak, Málovics Györgynek, Radácsi Lászlónak, Szigeti Cecíliának, valamint az anonim lektornak a kézirat korai változatához füzött konstruktív észrevételeikért.

Szennay Áron a BGE PSZK Pénzügy Tanszékének oktatója, a SZE RGDI doktorandusza, az MTA-BGE

Makrogazdasági fenntarthatósági kutatócsoport tagja.

A kézirat első változata 2020. január 31-én érkezett szerkesztőségünkbe.

DOI: http://dx.doi.org/10.18414/KSZ.2020.10.1057 
[2018] borúlátóbb, szerinte az ipari forradalom elötti állapothoz képest mért globális felmelegedés $1,5^{\circ} \mathrm{C}$-on belüli korlátozása is azonnali és jelentős beavatkozást igényel. ${ }^{1}$ További nehézséget okoz, hogy miközben a globális problémák (klímaváltozás, biodiverzitás csökkenése, népvándorlás, gazdasági növekedés kihívásai stb.) iránya, mértéke és a közöttük levő összefüggés sem minden esetben tisztázott tudományosan (például Kovács [2019]), a közbeszéd erősen tematizáltnak tekinthető. A társadalmi elégedetlenséget jól jelzik a különböző társadalmi mozgalmak (például Extinction rebellion, Friday for future), a természeti katasztrófákra irányuló kiemelt médiafigyelem vagy akár a „klímaszorongás” ${ }^{2}$ fogalma.

A környezetkárosításuk következtében a fejlett ipari országokban már az 1960-as évektől kezdve egyre több iparág került a környezetvédő csoportok célkeresztjébe, aminek következtében a vállalatok kommunikációja, müködése egyaránt egyre zöldebbé vált (Elkington [1994]). Ennek egyik jele, hogy a vezető amerikai vállalatok ügyvezetőit tömörítő Business Roundtable 181 tagja írta alá 2019-ben azt az állásfoglalást, amely szerint

„[A] vállalat célja, hogy valamennyi érdekeltjének, így a vevőknek, alkalmazottaknak, szállítóknak, helyi közösségeknek és a tulajdonosoknak hasznára legyen.” (BR [2019])

A vállalati szféra fenntartható fejlődéshez való hozzájárulásának megkerülhetetlenségét mutatja az is, hogy a 2015-ben az ENSZ 70. ülésszakán 193 tagállam által elfogadott fenntartható fejlödési keretrendszer (Agenda 2030) ${ }^{3}$ explicit módon felhívja az üzleti szféra szereplöit, hogy

„kreativitásukkal és innovációikkal járuljanak hozzá a fenntartható fejlődés által támasztott kihívások megoldásához" (ENSZ [2015] 29. o.).

A tanulmány célja a vállalati társadalmi felelösségvállalás (corporate social responsibility, CSR) különböző irányzatainak, menedzsmentmegközelítéseinek a fenntartható fejlődés fogalmához való viszonyának feltérképezése. A vállalati társadalmi felelősségvállalás leginkább különbözö, a vállalatok fenntarthatósággal kapcsolatos

\footnotetext{
${ }^{1}$ Az Éghajlatváltozási Kormányközi Testület (Intergovernmental Panel on Climate Change, IPCC) az ENSZ szervezete, amely az éghajlatváltozás tudományos alapjairól, annak hatásairól, a jövőbeli kockázatokról, valamint az alkalmazkodás és megelözés lehetséges módjairól közöl rendszeresen elemzéseket (https://www.ipcc.ch/about/).

${ }^{2}$ Az Amerikai Pszichológiai Társaság (American Psychological Association, APA) definíciója szerint a klímaszorongás (ecoanxiety) „a környezet pusztulásától való félelem”. A klímaváltozás egyedi (például adott természeti katasztrófa) vagy folyamatos hatásaival (például tengerszint emelkedése, időjárás változása) szembeni tehetetlenség akut vagy akár krónikus következményekkel is járhat (Clayton és szerzőtársai [2017]).

${ }^{3}$ Hivatalos nevén: Transforming our world: The 2030 Agenda for Sustainable Development. Magyarország az ENSZ Közgyűlésének 70. ülésszakán való magyar részvételről az 1604/2015. (IX. 8.) kormányhatározatban a magyar küldöttségnek megfogalmazott irányelvekben támogatta „a 2015 utáni fejlesztési/fenntartható fejlődési keretrendszert”. A 2016. évi 71., a 2017. évi 72., a 2018. évi 73., valamint a 2019. évi 74. ülésszakra vonatkozó irányelvek hasonlóan támogatják az Agenda 2030 megvalósításával kapcsolatos feladatokat (lásd rendre az 1498/2016., 1561/2017., 1316/2018., illetve 1461/2019. kormányhatározatokat). A 2020. évi 75. ülésszakra vonatkozó irányelveket a kézirat leadásakor még nem fogadták el.
} 
irányzatainak lazán kapcsolódó együttese, így az anyagban két meghatározó megközelítéssel, a megosztott értékteremtés (creating shared value, CSV), valamint a hármas optimalizáció (triple bottom-line, TBL) fenntartható fejlődéssel való kapcsolatával foglalkozom részletesebben.

A tanulmány teljes egészében szekunder kutatásnak tekinthető, a meglévő szakirodalmi források alapján, azok ütköztetésével kívánja a vizsgált témát bemutatni és értékelni. Ennek megfelelően a következőkben elöször a fenntartható fejlődés fogalmát, megközelítéseit, azok vállalatokhoz való kapcsolódását mutatja be, valamint a társadalmi felelösségvállalás szakirodalmát foglalja össze. Majd a két kiemelten vizsgált menedzsmentmegközelítés kapcsolódását elemzi a vállalati társadalmi felelősségvállalás szakirodalomához. Az írást a főbb következtetések zárják.

\section{A fenntartható fejlődés kapcsolata a vállalati felelősségvállalással}

A fejezet három részre tagolódik: 1. a fenntarthatóság és a fenntartható fejlődés definíciója, valamint a fogalmak közgazdasági megközelítései; 2 . a vállalatok társadalmi felelősségvállalásának kialakulása, elméleti keretei, kritikái; 3 . a vállalatok társadalmi felelősségvállalása és gazdasági teljesítménye közötti kapcsolatra vonatkozó megközelítések.

\section{A fenntartható fejlödés közgazdasági megközelitései}

A fenntartható fejlődés legismertebb definíciója a Brundtland-jelentésben szerepel, amely szerint

„a fenntartható fejlödés olyan fejlődés, amely biztosítja a jelen szükségleteinek kielégítését anélkül, hogy veszélyeztetné a jövő generációk szükségleteinek kielégítését" (WCED [1987] 3. pont 27. bekezdés).

Azáltalános megfogalmazás következtében azonban a definíciót máig értelmezési viták övezik (Tóth [2007], Kerekes és szerzötársai [2018]). Daly [2007] a gyakorlatban jobban alkalmazható definíciója szerint a gazdaság akkor fenntartható, ha 1. a felhasznált megújuló erőforrások időszaki felhasználása nem haladja meg azok újratermelődését; 2. a nem megújuló erőforrások felhasználása nem gyorsabb, mint azok megújuló helyettesítőinek fejlesztése; 3 . a szennyező anyagok kibocsátása nem lépi túl az azokat elnyelő kapacitásokat. Costanza-Patten [1995] definíciója a korábbiakhoz mérten kevésbé emelkedett: „egy rendszer fenntartható, ha túlél vagy kitart”. A szerzőpáros hozzáteszi, hogy a fenntarthatóság meghatározásához három kérdést kell tisztázni: 1. mely (al)rendszerre terjed ki a vizsgálat; 2. milyen időintervallumban értelmezzük; 3. mivel a fenntarthatóságot csak expost lehet kimondani, ezért előbb azt szükséges elöre jelezni, hogy a rendszer mely része(i) maradnak fenn, a maradék bizonytalanságot pedig egyéb intézkedések, eszközök alkalmazásával kell kezelni. A társadalmi-gazdasági rendszer nagyfokú bizonytalanságára való tekintettel célszerủ a beavatkozásokat elővigyázattal, 
csupán a feltétlenül szükségesnek tartott kockázat vállalásával kiválasztani, elkerülve a remélt technológiai megoldásokra való túlzott támaszkodást.

A fenntartható fejlődéssel kapcsolatos közgazdasági párbeszéd különböző irányzatainak alapját rendszerint a fenntarthatóság gyenge vagy erős definíciójáról alkotott álláspont határozza meg. A gyenge meghatározás szerint elegendő, ha a teljes tőkeállomány, azaz a természeti, a mesterséges, valamint az egyéb tőkeelemek összege nem csökken, vagyis a természeti tőke más tőkeelemekkel helyettesíthető. Az elmélet alapján a természeti erőforrások felhasználása növeli az árat, ami elösegíti az őket kiváltó, ökológiai szempontból hatékonyabb technológiák kifejlesztését (Málovics-Bajmócy [2009], Málovics [2020]). Ezzel szemben a fenntarthatóság erős definíciója szerint a természeti tőke és más tőkeelemek között nem helyettesítési, hanem kiegészítő kapcsolat van (Daly [2007], Málovics-Bajmócy [2009], Málovics [2020]). A valóság a kettő között van, ugyanis a természeti erőforrások egy része az élet, illetve az ökoszisztéma fenntartásához kritikusnak tekinthetö, míg másik részük megújuló, pótolható vagy helyettesíthetö (Elkington [1997] 396. o., Brand [2009]). Az emberi szükségletek jellegéből adódóan pedig a technológiai fejlődés csak részben képes mérsékelni a természeti erőforrások felhasználását (Tóth [2007], Kerekes és szerzőtársai [2018]).

\section{1. ábra}

A fenntartható fejlődésről szóló nézetek tipizálása

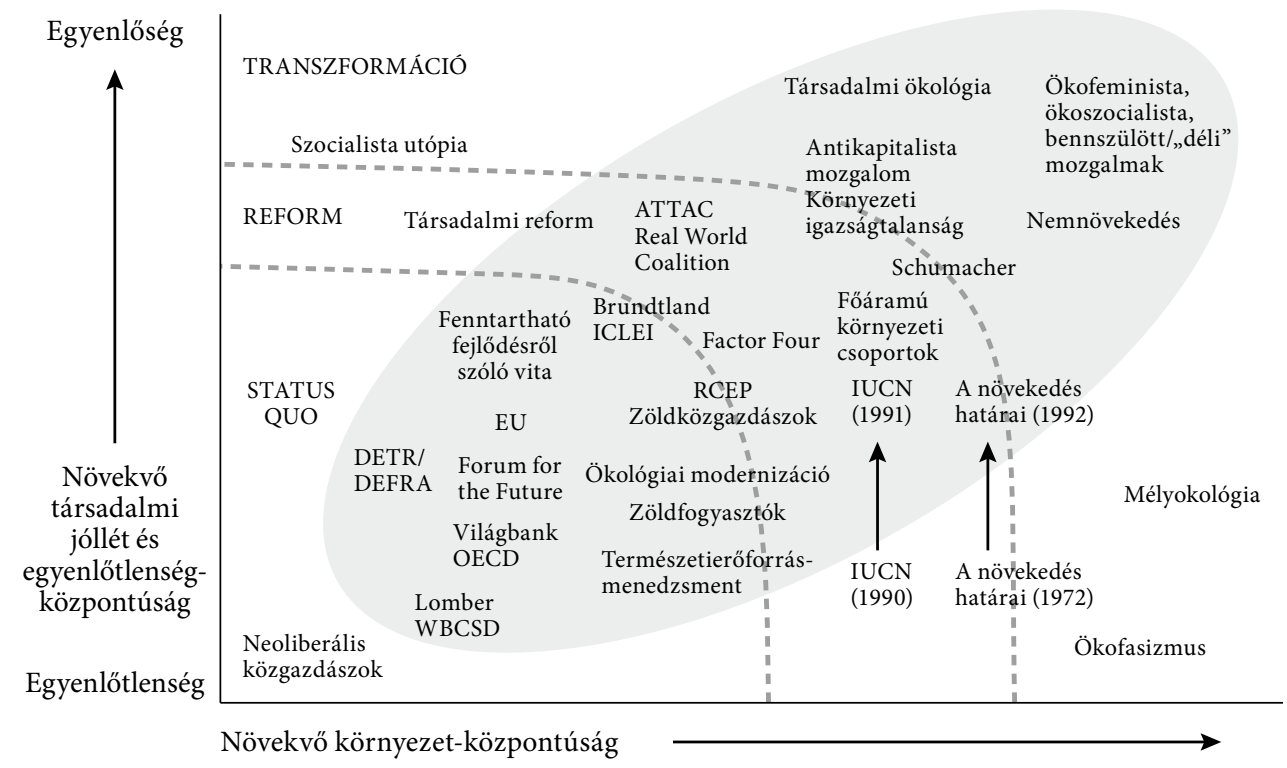

Rövidítések: ATTAC - Association for the Taxation of financial Transactions and Aid to Citizens; DETR/DEFRA - Department of Environment, Transport and the Regions/ Department for Environment, Food and Rural Affairs; ICLEI - Local Governments for Sustainability; IUCN - International Union for Conservation of Nature; OECD - Organisation for Economic Co-operation and Development; RCEP - Regional Comprehensive Economic Partnership; WBCSD - World Business Council for Sustainable Development.

Forrás: Hopwood és szerzőtársai [2005], Dombi-Málovics [2015] 207. o., Málovics [2020] 16. o. 
A fenntartható fejlődéssel kapcsolatos nézeteket Hopwood és szerzőtársai [2005] elemezte, és a fenntarthatóság társadalmi (egyenlőség), illetve környezeti pillére (ökoközpontúság) szerint rendezte (1. ábra).

Az elemzés alapján jól látható, hogy a folyamatokra legnagyobb befolyással lévő intézményi szereplők (Európai Unió, Világbank, OECD), valamint az üzleti szervezeteket tömörítő WBCSD rendre a status quo oldalán állnak, azaz a fenntartható fejlődést a jelenlegi rendszer kisebb kiigazításai mellett képzelik el.

\section{A vállalati felelösségvállalás kialakulása és elméleti háttere}

Számos megközelítés foglalkozik az üzleti szféra fenntarthatósághoz, illetve a fenntartható fejlődéshez való kapcsolatával, az ahhoz való hozzájárulásával. Ezek között a vállalati társadalmi felelösségvállalás (corporate social responsibility, CSR) terjedt el a leginkább. Ennek irodalma fél évszázados múltra tekint vissza (például BragdonMarlin [1972]), továbbá mind a cikkek számosságát, mind az irányzatait tekintve rendkívül gazdagnak tekinthető. Ennek ellenére a vállalati társadalmi felelősségvállalás jelenleg is a diszciplinarizálódás szakaszában van (Braun [2013]), az elméleti vitákat, a fogalmak meghatározását eddig nem sikerült lezárni, sőt a fogalmak és az elméleti irányzatok száma folyamatosan nő (Géring [2018]). Matten-Moon [2008] szerint a szakirodalom megalapozottsága ellenére is felmerülő definíciós nehézségeket az okozza, hogy a vállalati társadalmi felelősségvállalás

1. versengő fogalom, és alkalmazásának szabályai viszonylag nyitottak;

2. ernyőfogalom, amely több másik, a társadalom és gazdaság közötti kapcsolatokkal foglalkozó fogalommal fed át, vagy épp szinonim azokkal;

3. dinamikusan változó fogalom.

Az Európai Bizottság közleménye szerint a vállalati társadalmi felelősségvállalás

„a társadalmi és környezeti szempontoknak a vállalatok müködésébe és az érdekeltekkel való kapcsolataiba való önkéntes alapú integrációja" ( $E B$ [2002] 5. o.),

azaz a felelősségvállalás mindenképp a jogszabályi kötelezettségen túlmutató tevékenységet jelent.

A vállalati társadalmi felelösségvállalás alapelve, hogy az üzleti szervezet nem független a környezetétől (Pataki-Radácsi [2000]), a közösségek, illetve országok, valamint a vállalkozások sikere vagy bukása rendre összekapcsolódik. Ebböl következik, hogy az elért sikerekből a közösségeknek is részesülniük kell. Ez az összekapcsolódás ennyire tiszta formában csak olyan gazdasági rendszerben müködhet, ahol a gazdasági hatalom magánvállalkozások kezében van, így a vállalati társadalmi felelősségvállalás gyökerei nem a római maecenasok körében keresendök, hanem a 19. század vadkapitalizmusának iparmágnásaiéban, akik élesen elkülönítették azt, hogy hogyan lehet profitot elérni, valamint azt, hogy a tulajdonosok a megszerzett vagyonukat mire használják fel (Scherer és szerzőtársai [2009]). 
A modern értelemben vett társadalmi felelősségvállalást Howard Bowen $\mathrm{Az}$ üzletemberek társadalmi felelősségvállalása című könyvéhez (Bowen [1953]) szokás kötni (például Győri [2012]), azonban a mű még nem a vállalat egésze, hanem a vállalatvezetők felelösségvállalását helyezi a középpontba. Természetesen a vállalatvezetők attitűdjei, ismeretei, viselkedése a vállalati társadalmi felelősségvállalás elemzése során megkerülhetetlenek (Benedek-Takácsné [2016], Győri [2012]). A vállalatvezetők és a részvényesek (tulajdonosok) között azonban az ügynökmegbízó kapcsolatra jellemző problémák merülhetnek fel a vállalatvezetők felelősségvállalásával kapcsolatban is. Friedman [1970] erre alapozva utasítja el a vállalatok felelősségvállalását, ugyanis az a vállalatvezetők egyéni értékítéletein alapul, miközben „a vállalkozás egyetlen felelőssége a tulajdonosok profitjának növelése”, és mivel minden egyéb társadalmi cél követése erőforrások felhasználását jelenti, így az „a részvényesek meglopása”. Azt ugyanakkor Friedman [1970] is elismeri, hogy a profit maximalizálásának a törvényekben, az etikai normákban lefektetett szabályok betartása mellett kell történnie.

Az üzletemberek és a vállalatok felelössége közötti kapcsot Goodpaster-Matthews [1982] tárja fel: az emberek csoportjai bizonyos helyzetekben képesek egyetlen személyként viselkedni. Így ha a vállalat racionálisan cselekszik, és figyelembe veszi müködésének másokra gyakorolt hatását, akkor felelös lehet (lásd még Győri [2012]).

A vállalati társadalmi felelösségvállalás az 1960-as években jelent meg, amikor a társadalmi változások egyszerre termeltek ki egy új, a korábbinál felelősebb vállalkozói réteget, valamint ekkor alakult ki az üzleti szféra nagyobb transzparenciájára vonatkozó társadalmi elvárás. A vállalati társadalmi felelősségvállalás formálisan nem jelent ennél sokkal többet: Archie B. Carroll mára klasszikusnak tekinthető piramismodellje alapján a vállalkozás felelőssége a gazdaságilag rentábilis működésre, a jogi, valamint az etikai követelményeknek való megfelelésre, továbbá a filantróp tevékenységekre terjed ki. Ez azt jelenti, hogy a felelös vállalkozást a nem felelös vállalkozástól kizárólag az ügyeket felkaroló filantróp tevékenysége különböztetheti meg (Carroll [1991]).

Bár a vállalati társadalmi felelősségvállalás az „üzleti etika sikersztorija”, és "majd minden nagyvállalat és egyre több kisebb szereplő foglalkozik a kérdéssel, a legtöbben a PR- és kommunikációs területtel kötik össze, és többnyire egyszerủ szponzorációt értenek alatta" (Györi [2008] 46. o.) A szponzoráció mögötti szándékoktól függetlenül azonban a vállalati támogatások még Magyarországon is jelentős mértékben járulnak hozzá a nonprofit szervezetek müködéséhez (például Radácsi [2016], Nárai-Reisinger [2008], Reisinger [2013]). A kritikák következtében számos, a vállalati társadalmi felelösségvállalást meghaladni kívánó megközelítés jelent meg. Ilyen például Visser [2011] CSR 2.0 megközelítése vagy a Porter-Kramer [2011] által kidolgozott és a későbbiekben a tanulmányban részletesen vizsgált megosztott értékteremtés (creating shared value, CSV). A vállalati társadalmi felelősségvállalás irodalmának korábbi írásaihoz ${ }^{4}$ hasonlóan mindkét

\footnotetext{
${ }^{4}$ Elkington [1997] a vállalatok hármas optimalizációjának módját és szükségességét kifejtve folyamatosan olyan megoldásokat javasolt, amelyek az üzleti siker veszélyeztetése nélkül teremt társadalmi értéket, és védi a környezeti erőforrásokat. Roddick-Miller [2000] is megjegyzi: a növekedés és a kiváló eredmény előfeltétele annak, hogy egy vállalkozás jót cselekedhessen.
} 
megközelítés alapeleme a vállalati értékteremtés, azaz a gazdasági szempont eröteljes súlya, így ez a vállalati társadalmi felelősségvállalás egyes irányzatai közös jellemzőjének tekinthető. A következőkben ennek gazdasági szempontjait vizsgáljuk részletesebben.

\section{A vállalati társadalmi felelösségvállalás gazdasági vetülete - az üzleti motívum}

A hagyományos, a neoklasszikus közgazdászok által leírt vállalkozás ${ }^{5}$ a modern piacgazdaságokban mára „nem eladható” - a fogyasztók számára fontos, hogy a megvásárolt termék, illetve szolgáltatás fenntartható vagy épp „felelős” legyen. Bár a vállalati társadalmi felelősségvállalás eredetileg nem erről szólt, a vállalatok felismerték, hogy az érintettek jóindulatának kivívása, valamint a jobb arculat, reputáció érdekében célszerủ a vállalati társadalmi felelősségvállalással foglalkozni, ugyanis az üzletileg is megtérülhet (Györi [2012]). A vállalkozások fenntarthatósággal, felelősségvállalással kapcsolatos tevékenységeinek (például ökoinnovációk, méltányos felvásárlási árak, tisztességes bérezés stb.) pozitív pénzügyi megtérülését a téma szakirodalma üzleti motívumnak nevezi. Schaltegger-Synnestvedt [2002] modellje (2. ábra) alapján vannak olyan projektek, amelyek a társadalmi és/vagy környezeti teljesítmény javítása mellett a gazdasági megtérüléshez is hozzájárulnak.

\section{2. ábra}

A környezetvédelmi intézkedések és a vállalat gazdasági teljesítménye közötti lehetséges kapcsolatok

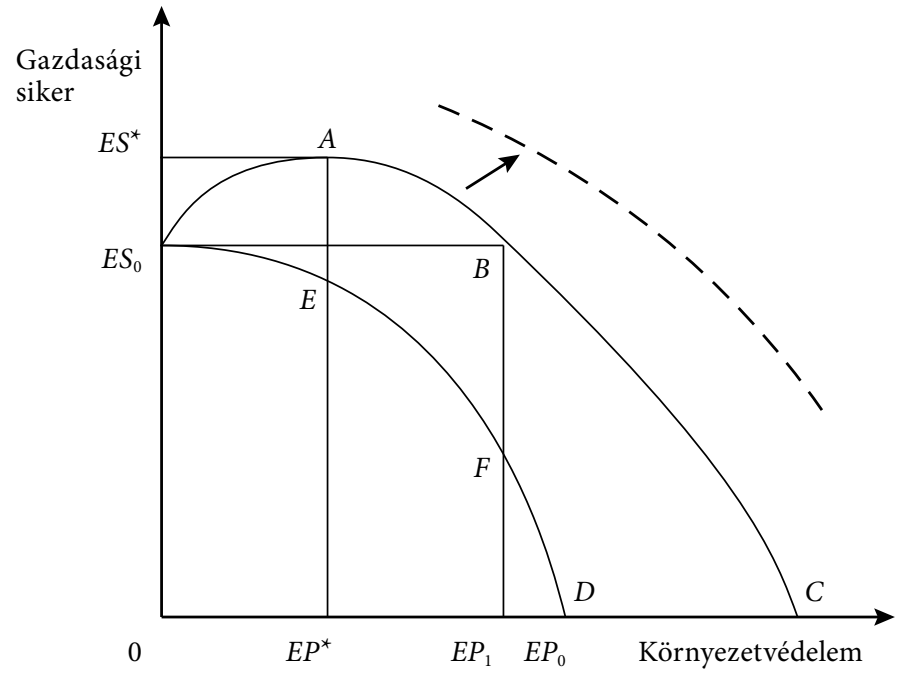

Forrás: Schaltegger-Synnestvedt [2002] 41. o.

${ }^{5}$ Friedman [1970] szavaival élve: „The business of business is business!”, azaz Tóth [2016] 176. o. fordításában: „A vállalatok dolga az üzlet és profit, nem más!” 
A vállalatvezetők tehát akkor járnak el helyesen, ha - a tőkekorlátokat is figyelembe véve - az összes pozitív megtérüléssel rendelkező projektet megvalósítják (az ábrán az $A$-val jelölt pont). Fontos hangsúlyozni, hogy a tulajdonosi érték egészen a $B$ pontig nem sérül, vagyis ez az üzleti motívum által elérhető hatás határa, a vállalkozás legfeljebb ennyi környezetvédelmi intézkedést valósít meg. ${ }^{6}$ Schaltegger-Synnestvedt [2002] kiemeli, hogy 1. technológiai vagy piaci változások következtében a görbe elmozdulhat, ami további intézkedéseket indokolhat gazdasági szempontból, 2. az $E S_{0}-A-B-C$ görbét a jól irányított cégek érhetik el. Ha a vállalatvezetés kevésbé jól ismeri fel a lehetőségeket, és/vagy kevésbé proaktív, akkor a lehetséges gazdasági teljesítmény-környezeti teljesítmény párok alacsonyabb görbéken helyezkednek el, s ez a környezeti teljesítménynek kisebb mértékü javulását eredményezi.

Bár modellszinten a felelősségvállalás és a nyereségesség közötti nyer-nyer kapcsolat alátámasztható, és a korlátok is könnyen meghatározhatók, normatív javaslatot tenni jóval nehezebb. Egyrészt amennyiben

„....a felelösebb vállalat valóban nyereségesebb is, akkor semmi szükség a társadalmi felelősség koncepciójára, hiszen a több profit érdekében úgyis mindent megtesz a cég." (Tóth [2007] 52. o.)

Másrészt a felelős működés ugyan rendszerint többletköltségekkel jár (például drágább technológiák alkalmazása, tisztességes felvásárlási árak a helyi termelöknek, a megélhetést biztosító jövedelmek biztosítása a munkavállalóknak stb.), a felelös működés szószólói számos pénzben kifejezhető, illetve nem vagy csak nehezen számszerüsíthető előnyt is figyelembe vesznek. Ilyen lehet többek között a lojálisabb munkaerö, a reputáció javítása, az elérhetö magasabb árak, de számos esetben költségcsökkenés is várható (például kevesebb csomagolóanyag, a hatékonyság javulása stb.). A pozitív és negatív hatások eredőjét a szakirodalmi források tovább taglalják, amiből a következőkben a teljesség igénye nélkül néhány megállapítást emelünk ki.

1. A felelősségvállalás és a jövedelmezöség közötti kapcsolat nem lineáris, hanem $U$ alakú, azaz a vállalati társadalmi felelősségvállalás ugyan rontja a rövid távú megtérülést, de hosszabb távon a piaci átlag feletti eredmény várható (Taliento és szerzőtársai [2019]).

2. A pénzügyi jövedelmezőség azonos szintjén is eltérhet a környezeti teljesítmény, és fordítva. Míg elöbbi esetben az ok a környezettel szembeni közöny vagy épp a felelösségvállalás szintje, utóbbi esetben menedzsmenthibák következtében nem feltétlenül realizálódik a hatások egésze. Ez azt jelenti, hogy belső tényezők - így a vállalatvezetés kvalitásai - is befolyásolhatják a két tényező közötti kapcsolatot (Schaltegger-Synnestvedt [2002]).

3. A felelösségvállalás bizalmi ügy is, ami azt jelenti, hogy a tevékenység eredménye az érintett szereplők (stakeholderek) közös cselekvéseinek, kommunikációjának, elvárásainak, illetve várakozásainak eredményeként áll elő. A vállalati társadalmi felelösségvállalás legjobb projektje is meghiúsulhat, ha egy vagy több fél bizalmatlan, rosszhiszemü,

\footnotetext{
${ }^{6}$ Az ábrán a környezeti teljesítmény látható, de ez teljes mértékben fennáll a társadalmi teljesítmény esetében is.
} 
vagy csak eltérő kultúrában szocializálódott. Kelet-Közép-Európa különösen jó példa erre, ugyanis még a 21. század elején is érezhető az egykori szocialista rendszer „öröksége" e téren (vállalati üdülők, sportlétesítmények stb. - lásd Kerekes-Wetzker [2007]), ugyanakkor a nyugati minták nehezen gyökeresednek meg (Radácsi [2011]).

4. A felelősségvállalásnak számos definíciója, ebből adódóan több indikátora, illetve mérőszáma is rendelkezésre áll, amelyek alapján nem feltétlenül megkülönböztethetö a felelós és a felelösebb vállalat, de az is előfordulhat, hogy amíg egy definíció alapján felelősnek tekinthető egy vállalat, addig egy másik szerint nem. Például egy tejfeldolgozó felelős akkor, ha a piaci viszonyokat kiegyensúlyozandó, folyamatosan méltányos árat fizet a helyi gazdáknak, és emellett tisztességes bért ad a munkavállalóinak, de nem feltétlenül rendelkezik például ISO 9001 tanúsítvánnyal vagy tesz közzé nem pénzügyi jelentést.

5. A felelősségvállalással kapcsolatos kiadások forrása a vállalat által kigazdálkodott profit. Ez azt is jelenti, hogy a tulajdonosok - mint elsődleges érdekelt felek által elvárt jövedelem mellett a vállalkozás fordíthat pénzt egyéb társadalmi, illetve környezeti célokra is (Roddick-Miller [2000]).

Figyelemmel arra, hogy a vállalatok müködésének gazdasági eredménye (részvényárfolyam, cégérték), valamint hatásai (például fluktuáció, munkahelyi balesetek száma, különböző káros anyagok kibocsátása stb.) jól mérhetők, az üzletimotívum-alapú vállalati társadalmi felelősségvállalás empirikusan is vizsgálható. Az empirikus vizsgálattal szemben kritikaként fogalmazható meg, hogy amíg a pénzügyi teljesítmény számviteli alapú megtérülési mutatókkal vagy piaci értékelések alapján könnyen és egzakt módon mérhető, addig a felelös müködéssel számos indikátor(készlet) kapcsolatba hozható, így az eredményben szükségképpen bizonytalanságok is vannak. A témában a Bragdon-Marlin [1972] tanulmány óta számos kutatás történt, amelyek eredményeit több metaelemzésben is vizsgálták. A legnagyobb ilyen elemzést Margolis és szerzőtársai [2009] készítette, amelyben 251 tanulmány, a pénzügyi és a nem pénzügyi teljesítmény közötti kapcsolatot vizsgáló írás eredményeit vetették össze. Az eredmények alapján a társadalmi és a pénzügyi teljesítmény között gyenge, de szignifikáns pozitív kapcsolat figyelhető meg, amit az érzékenységvizsgálatok is megerösítenek.

\section{A menedzsmentmegközelítések viszonya a vállalati társadalmi felelősségvállaláshoz}

\section{A „megosztott értékteremtés”}

A megosztott értékteremtés (creating shared value, CSV) fogalmát Porter-Kramer [2011] hozta be a köztudatba. A megközelítés népszerűségét mutatja, hogy a cikkre a Google Scholar szerint jelen cikk írásakor több mint 10 ezer hivatkozás történt (míg a 20 évvel korábbi CSR-piramisról szóló Carroll [1991]-re 12 ezer). A megosztott értékteremtés a szerzők szerint 
„nem társadalmi felelősségvállalás, filantrópia vagy akár fenntarthatóság, hanem a gazdasági siker elérésének új módja. Nem marginális vállalati tevékenység, hanem annak központi eleme." (Porter-Kramer [2011] 4. o.)

A megosztott értékteremtés lényege, hogy a vállalati értékteremtés nem szigetszerüen, a vállalat telephelyein történik, hanem a vállalatnak a társadalom integráns részének kellene lennie - részei a munkatársak, a meglévő és potenciális fogyasztók, a vállalati telephelyet befogadó település lakói és a beszállítók (Porter-Kramer [2011]). A gyakorlatban ez történhet 1. termék- és/vagy piacfejlesztéssel (például a kevésbé tehetős fogyasztók számára is megfizethető termékek előállításával); 2. az értéklánc átalakításával (például erőforrásokkal való hatékonyabb gazdálkodás, beszállítók fejlesztése); 3. helyi gazdasági klaszterek létrehozásával. A fogalmat Kramer-Pfitzer [2016] annyiban egészíti ki, hogy ha a vállalat megosztott értékteremtési stratégiájának megvalósítása valamilyen akadályba ütközik, akkor azt a többi érintett bevonásával közösen célszerü felszámolni. ${ }^{7}$ A szerzők egyik példája a Walmart esete: a beszállítók nem jutottak elegendő újrahasznosított müanyaghoz, ugyanis 2013-ban az Egyesült Államokban a városi lakosság 45 százaléka olyan helyen élt, ahol a hulladékot egyszerüen lerakóban helyezték el, az újrahasznosítható anyagok válogatása nélkül. A vállalkozás a probléma megoldására városvezetők, vállalatok, civilek, újrahasznosítók és pénzügyi szakértők bevonásával egy szektorközi együttmüködést hívott életre. Az együttmüködés végül tíz városban indított projektet, aminek eredményeként jelentősen csökkent a kezelés nélkül lerakott hulladék mennyisége, és munkahelyek jöttek létre.

A modern és fejlett piacgazdaságokban a termékfejlesztés, a keresleti igényeknek való egyre jobb megfelelés a piaci részesedés megőrzésének és növelésének legfontosabb eszköze (Porter-Kramer [2011]). Jó példa erre, hogy az élelmiszeripari és a kozmetikai ipari cégek egyre nagyobb hangsúlyt helyeznek a mesterséges összetevők mellőzésére (például „E-mentes élelmiszerek”, természetes alapú kozmetikumok), a természetes anyagokból és/vagy hagyományos módszerrel készült termékekre (például biológiailag lebomló tisztítószerek). E fejlesztések azonban továbbra is rendszerint a közepes vagy magas árfekvésü termékeket érintik. A piacfejlesztés ezzel szemben a Prahalad [2006] által a piramis aljának nevezett rétegeket, vagyis a nehezebben elérhető és/vagy kevésbé tehetős fogyasztókat érinti akár a harmadik világban. Hagyományos termékekkel és módszerekkel ezek a fogyasztók nem érhetők el, életminőségük javítása - valamint a vállalati jövedelemtermelés - csak új, kreatív módon valósítható meg (Porter-Kramer [2011]). Abban az esetben, ha az innovatív megoldás a várt társadalmi/gazdasági célokat eléri, de elmarad a vállalkozás profitvárakozásaitól, akkor érdemes lehet a projektet leválasztani a cég egészéről. Kockázatosabb esetben kormányzati vagy karitatív források bevonása megoldást kínálhat, és csak üzleti siker esetén kellene a projektet a vállalkozás egészébe integrálni (Pfitzer és szerzőtársai [2013]).

\footnotetext{
${ }^{7}$ A fogalom alapja egy másik fogalom: a közösségi cselekvés (collective impact) (Kania-Kramer [2011]), amely a társadalmi és környezeti célokért való közös, többszereplős műveletek sikerét segíti elö.
} 
Az értéklánc átalakítása kapcsán Porter-Kramer [2011] a következő intézkedéseket sorolja fel: 1 . a szállítási útvonalak optimalizálása, kevesebb csomagolás, 2 . az energiafelhasználás és logisztika optimalizálása, 3 . az erőforrások hatékonyabb felhasználása, 4. a beszállítói lánc fejlesztése (lásd még Kramer-Pfitzer [2016]). A szerzők érvelése szerint ezek az intézkedések - az alacsonyabb költségek és/vagy magasabb bevételek következtében - nemcsak a vállalatnak, hanem a környezet és/vagy a különböző érdekeltek számára is értéket teremtenek. Ilyen érték lehet például a környezet védelme, az üvegházhatású gázok kibocsátásának mérséklése, beszerzés a helyi termelőktől vagy éppen a beszállítók célzott fejlesztése.

Az értéklánc átalakításával kapcsolatban két kritika is megfogalmazható. 1. A méltányos kereskedelemmel (fair trade) szemben a megosztott értékteremtés az elosztható jövedelem növelése által teremt minden szereplő számára előnyösebb helyzetet (Porter-Kramer [2011]). A banántermelés jó példa, ugyanis a helyi gazdálkodók termelte trópusi gyümölcs az egész világon elérhető. A tényleges termelők nem méltányos kereskedelem esetén a kiskereskedelmi ár körülbelül 10 százalékát kapják, míg a fennmaradó 90 százalékon körülbelül fele-fele arányban osztoznak a kiskereskedők és az oligopolhelyzetben levő nemzetközi banánvállalatok (Tóth [2016]). Ez azt jelenti, hogy az utóbbi két szereplő hasznának kismértékủ csökkenése - ugyanolyan volumen és ár mellett - a termelők bevételének jelentős növekedését okozná. 2. A Porter-Kramer [2011] által javasolt akciók mindegyike megjelenik a vállalati társadalmi felelősségvállalást mint üzleti motívumot vizsgáló szakirodalomban. A megosztott értékteremtés jelentette többlet e tekintetben kizárólag a külső érdekeltek számára nyújtott előnyök erősebb kommunikációjára szorítkozik, ami az üzleti szereplők iránti nagyobb fokú bizalmat segítheti elö.

A helyi gazdasági klaszterek létrehozása lényegében nem különbözik a regionális tudományokban szereplő elméletektől. A vállalati társadalmi felelősségvállalás ezen eleme lényegében megegyezik Porter korábbi, az ipari klasztereket a vállalati/regionális versenyelőny alapjaként bemutató cikkével (lásd Porter [1998]). Eszerint a vállalat helyi gazdasági tevékenységének tovagyürüző hatásai (például a kifizetett bérek nyújtotta jobb életszínvonal, nagyobb fogyasztás stb.), a helyi beszállítóknak nyújtott megrendelések, a közös innováció jelentős helyi gazdaságfejlesztési hatást gyakorolnak, ami elönyös mind a vállalatnak, mind a társadalomnak. ${ }^{8}$ A korábbi cikk(ek)hez képest az egyetlen lényegi újdonság, hogy új vállalati telephely létrehozása esetén a telepítési tényezők azonossága mellett a vállalatnak azt a telephelyet kell választania, ahol a beruházás nagyobb társadalmi hatást érhet el (Porter-Kramer [2011]).

A megközelítés 2011 elején történt publikálása alapján vélelmezhető, hogy az üzleti szektornak a globális pénzügyi válságban megroppant reputációja, a nagyvállalatokkal szembeni bizalom csökkenése is hozzájárulhatott a kapitalizmus közös értékteremtésen alapuló újrafogalmazása iránti igényhez. Eredményeink alapján azonban a vállalati társadalmi felelösségvállalás nem definiálja újra a kapitalizmust, rendszerint üzleti motívumait alkalmazza, a megközelítés az érintetti elmélet és a vállalati

\footnotetext{
${ }^{8}$ Győr és az Audi Hungária együttműködéséről lásd például Rechnitzer [2016] vagy FeketeRechnitzer [2019].
} 
társadalmi felelősségvállalás már meglévő elméleteihez képest lényegesen újat nem képvisel (Kim [2018]). Sőt, mivel a megosztott értékteremtés eszközei a vállalat társadalmi, illetve környezeti teljesítményének optimalizálását szolgáló beruházások kiválasztását és megvalósítását támogatják, így a beavatkozások csak fokozatos változást eredményezhetnek, a fenntarthatóság eléréséhez szükséges transzformatív változást nem (de los Reyes-Scholz [2019]). Így a megközelítés Hopwood és szerzötársai [2005] térképén a status quo mezőjében (1. ábra), feltehetően a WBCSD által képviselt irányvonalhoz közel helyezkedhet el. A megosztott értékteremtésnek a status quo területén való elhelyezése azt is jelenti, hogy az irányzat a fenntarthatóság gyenge definícióját veszi alapul - a vállalat legfőbb célja az értékteremtés, azonban azt pozitív összegü játéknak tekinti, ahol megfelelő versenystratégiák következtében valamennyi érintett fél (helyi közösségek, beszállítók stb.) a korábbinál előnyösebb helyzetbe kerülhet. Fontos kiemelni azonban, hogy a megosztott értékteremtés az emberek jólétére koncentrál, azaz kifejezetten antropocentrikus megközelítés, a környezeti szempontokat elsősorban a hatékonyabb értékteremtés tovagyürüző hatásaként veszi figyelembe.

\section{Hármas optimalizálás}

Vitán felül áll, hogy a vállalati társadalmi felelősségvállalás a vállalkozás erőforrásainak a szűken vett tulajdonosi értékteremtéstől eltérő felhasználásával jár. Az üzleti motívumot hangsúlyozó szerzők szerint azonban - ahogy azt fentebb már bővebben kifejtettük, a vállalati felelősségvállalás számos, pénzben kifejezhetö, illetve nem számszerüsíthető haszonnal is járhat. Ezen gondolatmenet alapján született meg a kettős (double bottom line, DBL) és a hármas optimalizálás (triple bottom line, TBL) menedzsment-keretrendszere, amely alapján a vállalkozás céljai között a gazdasági eredményesség mellett, azzal azonos súllyal jelenhetnek meg a környezeti és a társadalmi célok (Elkington [1997]). A hármas optimalizálás népszerüségét jelzi, hogy a rendszert már a kezdetektől számos vállalkozás sikerrel vezette be (például CohenGreenfield [2000]), továbbá e megközelítés szogál a nem pénzügyi jelentéstételek alapjául is (például Global Reporting Initiative, GRI). Ugyanakkor Sridhar-Jones [2013] alapján a megközelítés három legfőbb hiányossága, hogy 1 . nehezen összevethetö a környezeti, a társadalmi és a gazdasági dimenziókban mért teljesítmény, 2. amenynyiben a vállalkozás teljesítménye valamely területen kiemelkedik, lehetőség adódik más területen jelentkező gyengébb teljesítmény kompenzációjára, 3. valódi felelösségvállalás helyett csupán megfelelésre (compliance) ösztönöz.

A gazdasági, társadalmi és környezeti teljesítmény eltérő indikátorokkal mérhető, az eredmények pedig nem vagy csak nehezen vethetök össze (például Tóth [2007]). A gazdasági teljesítmény tekintetében rendelkezésre állnak bevett és a gyakorlatban használt teljesítménymutatók, sőt a környezeti teljesítmény mérésére is számos specifikus mutató áll rendelkezésre. Ilyen lehet például az üvegházhatású gázok kibocsátása, más szennyező- vagy épp mérgezőanyag-kibocsátás. Azonban e tekintetben számos átváltás (trade-off) tárható fel - például a dízelautók $\mathrm{CO}_{2}$-kibocsátása a benzinesekénél kisebb, de több helyi légszennyezö anyagot bocsátanak ki, ami 
városi környezetben a levegőminőség romlását okozza. A társadalmi hatás mérése még problémásabb, ugyanis az indikátorok (például a helyi közösségek támogatása, a maximális és minimális bérek hányadosa stb.) csupán egy-egy részterületre terjednek ki, nem adhatók össze, továbbá számos esetben a célérték meghatározása is nehézségekbe ütközik. A társadalmi hatás mérési nehézségeit mutatja, hogy a jelentéstételi keretrendszer (GRI) esetében a társadalmi indikátorok felülreprezentáltak (Moneva és szerzőtársai [2006], Szennay-Szigeti [2019]). Bár a három pillér teljesítménye indexszámítással, pénzértékben való kifejezéssel összegezhető (Slaper-Hall [2011]), ezek a megoldások jelentős torzításokat okozhatnak.

A kettős vagy hármas eredménykritériumok lehetőséget biztosítanak az egyes pillére(ke)n mért rossz teljesítmény másik dimenzióban való kompenzálására, amely a fenntarthatóság gyenge definíciójához való hasonlóságot mutatja. Mivel ez ellenkezik a fenntarthatóság holisztikus szemléletével, ezért Sridhar-Jones [2013] a koncepció átdolgozását, a teljesítménymutatók összevonását (integrated bottomline, $I B L)$ javasolják.

A nem pénzügyi beszámolás intézményesülésével a vállalatok rendszerint a beszámoló elöírásainak, az abban megadott indikátorkészletnek való megfelelést tekintik célnak, amelyet nem feltétlenül egészítenek ki a saját müködésüknek, értékteremtésüknek megfelelö további lényeges indikátorokkal. Ugyanakkor az érdekeltek (stakeholderek) elvárásai, a jelentéstétel önkéntessége és a beszámolók tartalmában való relatív szabadság is hozzájárulhat a jelentések számának növekedéséhez, valamint azok részletesebbé válásához (Pintér és szerzőtársai [2012]). Bizonytalanságot okoz azonban, hogy 1. a nem pénzügyi jelentéshez nem kapcsolódik a pénzügyi adatok hitelességét biztosító könyvvizsgálói audithoz hasonló ellenőrzés (Laufer [2003]), független fél (NGO vagy könyvvizsgáló cég) rendszerint csupán a beszámolót hitelesíti (Knebel-Seele [2015]), továbbá 2. mivel az érdekeltek döntéseiket a közzétett adatok - így a beszámolóban szereplő információk - alapján hozzák meg, így a beszámoló alkalmas lehet a „zöldre mosásra” (Györi [2012]). Ezt a nézetet erösíti, hogy ZsókaVajkai [2018] szerint a cégek túlnyomó többségének nem pénzügyi jelentéseiben kizárólag pozitív információk szerepeltek, ugyanakkor a müködésük fenntarthatósághoz való hozzájárulásánál negatív hatásokról is számot adtak.

A hármas optimalizálás egyszerü és könnyen megérthetö megközelítés, amely magában hordozza annak lehetőségét, hogy a vállalkozás figyelembe vegye valamenynyi hatását. További előnye, hogy nemcsak a nagyvállalatok esetében, hanem a kis- és középvállalkozások, sőt más szervezetek számára is alkalmazható. Azonban a hármas optimalizálásnak való formális megfelelés alkalmat ad a valós hatások elfedésére, kompenzálására. A megosztott értékteremtéssel ellentétben a hármas optimalizálás elhelyezése jóval nehezebb a Hopwood és szerzőtársai [2005] által alkotott térképen. Az Elkington [1997] által kidolgozott megközelítés szellemisége értelmében a szervezet a döntései során azonos súllyal veszi figyelembe valamennyi - társadalmi, környezeti és gazdasági - hatást, ezáltal a megfelelő elhelyezkedés a status quo és a reform jelentette területek határvonalán, a társadalmi egyenlőségtől és az ökoközpontúságtól azonos távolságra helyezkedik el. Nehéz megítélni azt, hogy ez a megközelítés teljesíti-e a fenntarthatóság erős definíciójának kritériumait, de mindenképpen közel áll 
hozzá. Ugyanakkor a hármas optimalizálás a korábban jelzett csatornákon keresztül (lásd a különböző hatások összegzésének nehézsége, a különböző hatások kompenzációja, a szervezetek megfelelésre való törekvése) nem biztos, hogy a fenti szellemiségben valósul meg - ekkor a térképen a megosztott értékteremtéssel azonos területen, a WBCSD által képviselt álláspont közelében helyezkedik el, vagyis csupán a fenntarthatóság gyenge definíciójának felel meg.

\section{Összefoglalás és következtetések}

Összefoglalásként megállapítható, hogy bár a vállalati társadalmi felelősségvállalás, a megosztott értékteremtés és a hármas optimalizálás mindegyike esetén feltárhatók olyan hatások, amelyek hozzájárulnak a fenntarthatósághoz (például innovatív termékek az alacsony vásárlóerejü fogyasztóknak, hulladéktermelés csökkentése és/vagy újrahasznosított anyagok felhasználása, etikai kódexek megfogalmazása és alkalmazása stb.), ezek határát az üzleti szempontok egyértelmúen kijelölik. Ez azt is jelenti, hogy a vizsgált megközelítések mindegyike a fenntarthatóság gyenge definíciójához áll közel, vagyis az újratermelődő természeti tőke és a mesterséges tőke között helyettesíthetőségi kapcsolatot feltételez.

Bár Porter-Kramer [2011] a megosztott értékteremtést „a kapitalizmus modelljének újradefiniálásaként", a vállalati társadalmi felelősségvállalást meghaladni kívánó menedzsmentmegközelítésként mutatja be, a megközelítés által javasolt eszközök, beavatkozások nem térnek el lényegesen a vállalati társadalmi felelősségvállalás esetében alkalmazottaktól.

A hármas optimalizáció szintén jól kommunikálható menedzsmenteszköz, ugyanis explicit módon mutatja be a vállalkozás társadalmi, gazdasági és környezeti teljesítményét, az adott területen végzett eröfeszítéseit. Eredményeink alapján azonban a három pillér teljesítménye nehezen vethető és adható össze, valamint lehetővé teszi, hogy az egyes dimenziók kevésbé jó eredményeit egy másikban elért jó eredménnyel kompenzálják.

Figyelemmel arra, hogy a vállalati társadalmi felelősségvállalás mára a fóáramú vállalati müködés része lett, számos kutató, vállalatvezető, tanácsadó hívja fel a figyelmet arra, hogy a koncepció nem érte el a célját, ugyanis

„legtöbb vállalat (...) sajnálatos módon nem az etikai felelősség szükségszerűségének felismerése miatt, hanem a jobb imázsért, reputációért foglalkozik a felelősségvállalással" (Győri [2012] 60. o.).

Ugyanakkor, mivel az üzleti szervezetek felelösségvállalásával kapcsolatban, müködésük fenntarthatóbbá tételében társadalmi konszenzus uralkodik, ezért legitim igény a vállalati társadalmi felelősségvállalás hibáinak javítása. Mivel az új megközelítések megkülönböztetésének legjobb módja egy új betűszó alkotása, ez egyúttal lehetőséget ad a tanácsadók márkaépítésére (self-branding) a korábbi eredményeket, javaslatokat meghaladó új elgondolás nélkül is. Legfőbb következtetésünk, hogy ugyanazok a panelek és megoldások több eltérő megoldásban más névvel is megjelenhetnek. 
További kutatási irányként más népszerü megközelítések, valamint a kis- és középvállalkozások vállalati társadalmi felelősségvállalással kapcsolatos tevékenységének vizsgálata határozható meg, amelynek keretében megismerhető a végzett tevékenységek köre, azok motivációja, valamint az esetlegesen alkalmazott kommunikációs csatornák.

\section{Hivatkozások}

Benedek Andrea-Takácsné György Katalin [2016]: A felelős vállalatirányítás személyi tényezői: A CSR-központ felelős vállalatvezetők attitűdjének vizsgálata a kis- és középvállalatok körében. Vezetéstudomány, 47. évf. 1. sz. 58-70. o.

Bowen, H. R. [1953]: Social Responsibilities of the Businessman. University of Iowa Press, Iowa City.

BR [2019]: Business Roundtable Redefines the Purpose of a Corporation to Promote 'An Economy That Serves All Americans'. Augusztus 19. https://www.businessroundtable.org/ business-roundtable-redefines-the-purpose-of-a-corporation-to-promote-an-economythat-serves-all-americans.

Bragdon, J.-Marlin, J. [1972]: Is Pollution Profitable? Risk Management, Vol. 19. No. 4. 9-18. o.

BRAND, F. [2009]: Critical natural capital revisited: Ecological resilience and sustainable development. Ecological Economics, Vol. 68. No. 3. 605-612. o. https://doi.org/10.1016/j. ecolecon.2008.09.013.

BRAUN RÓBERT [2013]: A vállalatok politikája - vállalati, társadalmi felelősségvállalás, vállalati közösségek és a vállalati stratégia jövője. Vezetéstudomány, 44. évf. 1. sz. 18-28. o.

Carroll, A. B. [1991]: The pyramid of corporate social responsibility: Toward the moral management of organizational stakeholders. Business Horizons, Vol. 34. No. 4. 39-48. o. https://doi.org/10.1016/0007-6813(91)90005-g.

Clayton, S.-Manning, C.-Krygsman, K.-Speiser, M. [2017]: Mental health and our changing climate: Impacts, implications, and guidance. https:/www.apa.org/news/press/ releases/2017/03/mental-health-climate.pdf.

Cohen, B.-Greenfield, J. [2000]: Mit jelent az, hogy „érték-alapú” vállalat? Megjelent: Pataki György-Radácsi László (szerk.): Alternatív kapitalisták. Új Paradigma, Szentendre, 157-186. o.

Costanza, R.-Patten, B. C. [1995]: Defining and predicting sustainability. Ecological Economics, Vol. 15. No. 3. 193-196. o.

DALY, H. [2007]: Economics in a full world. Megjelent: Daly, H.: Ecological Economics and Sustainable Development. Selected Essays of Herman Daly. Edward Elgar, Cheltenham, UK, 12-25. o. https://doi.org/10.4337/9781847206947.

De los Reyes, G.-Scholz, M. [2019]: The limits of the business case for sustainability: Don't count on 'Creating Shared Value' to extinguish corporate destruction. Journal of Cleaner Production, Vol. 221. 785-794. o. https://doi.org/10.1016/j.jclepro.2019.02.187.

Dombi Judit-MÁlovics György [2015]: A növekedésen túl - egy új irányzat hozzájárulása a fenntarthatósági vitához. Közgazdasági Szemle, 62. évf. 2. sz. 200-221. o.

EB [2002]: Communication from the Commission concerning Corporate Social Responsibility: A business contribution to Sustainable Development. Brussels, 2.7.2002 $\operatorname{COM}(2002) 347$ final. https://eur-lex.europa.eu/LexUriServ/LexUriServ.do?uri=COM:2002:0347:FIN:EN:PDF. 
Elkington, J. [1994]: Towards the Sustainable Corporation: Win-Win-Win Business Strategies for Sustainable Development. California Management Review, Vol. 36. No. 2. 90-100. o. https://doi.org/10.2307/41165746.

Elkington, J. [1997]: Cannibals with Forks. The Triple Bottom Line of 21st Century Business. Capstone, Oxford.

ENSZ [2015]: Transforming our world: The 2030 Agenda for Sustainable Development. United Nations A/RES/70. http://www.un.org/ga/search/view_doc.asp?symbol=A/RES/70/1\&Lang=E.

Fekete Dávid-Rechnitzer János [2019]: Együtt nagyok. Város és vállalat 25 éve. Dialóg Campus Kiadó, Budapest.

FriedmAN, M. [1970]: The social responsibility of business is to increase its profits. The New York Times Magazine, szeptember 13. http://umich.edu/ thecore/doc/Friedman.pdf.

GÉRING ZsuzsanNA [2018]: A vállalati társadalmi felelősségvállalás kritikai megközelítései. A vállalati állampolgárság, az explicit/implicit CSR és az 'újrapolitizált' vállalat koncepció. Replika, 106-107. sz. 57-76. o. https://doi.org/10.32564/106-107.4.

Goodpaster, K. E.-Matthews, J. B. [1982]: Can a Corporation Have a Conscience? Harvard Business Review, január. https://hbr.org/1982/01/can-a-corporation-have-a-conscience.

GyőRi Zsuzsanna [2008]: A „CSR”-on innen és túl. Megjelent: Szigeti Cecília (szerk.): Konferenciakiadvány a vállalati felelősségvállalásról szóló konferencia előadásaiból. Széchenyi István Egyetem Kautz Gyula Gazdaságtudományi Kar, Győr, 46-59. o.

GYőRI Zsuzsanna [2012]: Első- és másodfajú etikai kudarcok. Vezetéstudomány, 43. évf. 10. sz. 56-63. o.

Hopwood, B.-Mellor, M.-O’Brien, G. [2005]: Sustainable development: mapping differenc approaches. Sustainable Development, Vol. 13. No. 1.38-52. o. https://doi.org/10.1002/sd.244.

IPCC [2018]: Summary for Policymakers. Megjelent: Global Warming of $1.5^{\circ} \mathrm{C}$. Special Report, IPCC, https://www.ipcc.ch/sr15/.

Kania, J.-Kramer, M. [2011]: Collective Impact. Stanford Social Innovation Review, Winter. KEREKES SÁNDOR-WETZKer KonRÁd [2007]: Keletre tart a „társadalmilag felelős vállalat” koncepció. Harvard Business Manager (magyar kiadás), 9. évf. 4. sz. 37-47. o.

Kerekes Sándor-Marjainé Szerényi Zsuzsanna-Kocsis Tamás [2018]: Sustainability, environmental economics, welfare. Budapesti Corvinus Egyetem, Budapest. https://doi. org/10.14267/cb.2018k05.

KIm, R. C. [2018]: Can Creating Shared Value (CSV) and the United Nations Sustainable Development Goals (UN SDGs) Collaborate for a Better World? Insights from East Asia. Sustainability, Vol. 10. No. 11. https://doi.org/10.3390/su10114128.

Knebel, S.-Seele, P. [2015]: Quo vadis GRI? A (critical) assessment of GRI 3.1 A+ nonfinancial reports and implications for credibility and standardization. Corporate Communications: An International Journal, Vol. 20. No. 2. 196-212. o. https://doi.org/10. 1108/CCIJ-11-2013-0101.

Kovács Róbert [2019]: Klímaváltozás. Pánik és tagadás között. Typotex Kiadó, Budapest.

Kramer, M. R.-Pfitzer, M. W. [2016]: The Ecosystem of Shared Value. Harvard Business Review, Vol. 94. No. 10. 80-89. o.

LAufer, W. S. [2003]: Social Accountability and Corporate Greenwashing. Journal of Business Ethics, Vol. 43. 253-261. o. https://doi.org/10.1023/A:1022962719299.

MÁLOviCs GYÖRGY [2020]: Ökológiai közgazdaságtan, átalakulás, társadalmi részvétel. JATE Press, Szeged.

MÁlovics György-Bajmócy Zoltán [2009]: A fenntarthatóság közgazdaságtani értelmezései. Közgazdasági Szemle, 56. évf. 5. sz. 464-483. o. 
Margolis, J. D.-Elfenbein, H. A.-Walsh, J. P. [2009]: Does it pay to be good, and does it matter? A meta-analysis of the relationship between corporate social and financial performance. http://dx.doi.org/10.2139/ssrn.1866371.

Matten, D.-Moon, J. [2008]: Implicit and explicit CSR: A conceptual framework for a comparative understanding of corporate social responsibility. Academy of Management Review, Vol. 33. No. 2. 404-424. o. https://doi.org/10.5465/amr.2008.31193458.

Meadows, D. H.-Meadows, D. L.-Randers, J.-Behrens, W. W. [1972]: The limits to growth. A Report for The Club of Rome's Project on the Predicament of Mankind. Universe Books, New York. http://www.donellameadows.org/wp-content/userfiles/Limits-toGrowth-digital-scan-version.pdf.

Moneva, J. M.-ArChel, P.-Correa, C. [2006]: GRI and the camouflaging of corporate unsustainability. Accounting Forum, Vol. 30. No. 2. 121-137. o. http://dx.doi.org/10.1016/j. accfor.2006.02.001.

NÁrai MÁrta-Reisinger Adrienn [2008]: Vállalati adományozás. A nonprofit szervezetek támogatása mint a vállalati társadalmi felelősségvállalás része. Megjelent: $S z i$ geti Cecília (szerk.): Konferenciakiadvány a vállalati felelősségvállalásról szóló konferencia előadásaiból. Széchenyi István Egyetem Kautz Gyula Gazdaságtudományi Kar, Győr, 138-153. o.

PAtAKi György-RAdácsi LÁszló [2000]: Alternatív üzleti vállalkozások. Megjelent: Pataki György-Radácsi László (szerk.): Alternatív kapitalisták. Új Paradigma, Szentendre, 157-186. o.

Pfitzer, M. W.-Bockstette, V.-Stamp, M. [2013]: Innovating for Shared Value. Harvard Business Review, Vol. 91. 100-107. o.

Pintér, L.-HARdi, P.-Martinuzzi, A.-HALl, J. [2012]: Bellagio STAMP: Principles for sustainability assessment and measurement. Ecological Indicators, Vol. 17. 20-28. o. https:// doi.org/10.1016/j.ecolind.2011.07.001.

Porter, M. E. [1998]: Clusters and the New Economics of Competition. Harvard Business Review, Vol. 76. No. 6. 77-90. o.

Porter, M. E.-Kramer, M. R. [2011]: Creating shared value. Harvard Business Review, Vol. 89. No. 1-2. 62-77. o.

Prahalad, C. K. [2006]: Esélyek a piramis alján. Társadalmi felelősségvállalás és profit. HVG Kiadói Rt., Budapest.

RADÁCsI LÁszLó [2011]: A közép-európai CSR paradoxon. Harvard Business Review (magyar kiadás), december, 28-39. o.

RADÁcsi LÁszLó [2016]: Üzleti és civil szervezetek együttmüködése Magyarországon. Megjelent: Radácsi László (szerk.): Üzleti és civil szervezetek együttmüködése Magyarországon. Publio Kiadó Kft., 5-42. o.

Rechnitzer János [2016]: A területi tőke a városfejlődésben. A Győr-kód. Dialóg Campus Kiadó, Budapest-Pécs.

Reisinger Adrienn [2013]: Social responsibility: the case of citizens and civil/nonprofit organisations. Tér-Gazdaság-Ember, 1. évf. 3. sz. 75-87. o.

Roddick, A.-Miller, R. [2000]: A szeretet hatalma. Megjelent: Pataki György-Radácsi László: Alternatív kapitalisták. Új Paradigma, Szentendre, 131-156. o.

Schaltegger, S.-Synnestvedt, T. [2002]: The link between 'green' and economic success: environmental management as the crucial trigger between environmental and economic performance. Journal of Environmental Management, Vol. 65. No. 4. 339-346. o. https:// doi.org/10.1006/jema.2002.0555. 
Scherer, A.-Palazzo, G.-Matten, D. [2009]: Introduction to the Special Issue: Globalization as Challenge for Business Responsibilities. Business Ethics Quarterly, Vol. 19. No. 3. 327-347. o. https://doi.org/10.5840/beq200919320.

Slaper, T. F.-Hall, T. J. [2011]: The Triple Bottom Line: What Is It and How Does It Work? Indiana Business Review, Vol. 86. No. 1. http://www.ibrc.indiana.edu/ibr/2011/spring/ article2.html.

SRIDHAR, K.-Jones, G. [2013]: The Three Fundamental Criticisms of the Triple Bottom Line Approach: An Empirical Study to Link Sustainability Reports in Companies Based in the Asia-Pacific Region and TBL Shortcomings. Asian Journal of Business Ethics, Vol. 2. No. 1. 91-111. o. https://doi.org/10.1007/s13520-012-0019-3.

Szennay Áron-Szigeti Cecília [2019]: A fenntartható fejlődési célok és a GRI szerinti jelentéstétel kapcsolatának elemzése. Vezetéstudomány, 50. évf. 4. sz. 33-43. o. https://doi. org/10.14267/VEZTUD.2019.04.04.

Taliento, M.-Favino, C.-Netti, A. [2019]: Impact of Environmental, Social, and Governance Information on Economic Performance: Evidence of a Corporate 'Sustainability Advantage' from Europe. Sustainability, Vol. 11. No. 6. https://doi.org/10.3390/su11061738.

Tóth Gergely [2007]: A valóban felelős vállalat. A fenntarthatatlan fejlődésről, a vállalatok társadalmi felelősségének (CSR) eszközeiről és a mélyebb stratégiai megközelítésröl. Követ Egyesület, Budapest. http://kovet.hu/wp-content/uploads/2018/04/0-A-Val\%C3\%B3banFelel\%C5\%91s-V\%C3\%A1llalat-1.pdf.

Tóth Gergely [2016]: Gazdasággép. L'Harmattan-Követ Egyesület, Budapest.

VISSER, W. [2011]: The Age of Responsibility: CSR 2.0 and the New DNA of Business. Wiley. WCED [1987]: Report of the World Commission on Environment and Development: Our Common Future. https://sustainabledevelopment.un.org/content/documents/5987ourcommon-future.pdf.

WEF [2020]: The global risk report. http://www3.weforum.org/docs/WEF_Global_Risk_ Report_2020.pdf.

Zsóka Ágnes-Vajkai Éva [2018]: Corporate sustainability reporting: Scrutinising the requirements of comparability, transparency and reflection of sustainability performance. Society and Economy, Vol. 40. No. 1. 19-44. o. https://doi.org/10.1556/204.2018.40.1.3. 